\title{
Kebiasaan Membaca Label Gizi Berhubungan Dengan Asupan Natrium Pada Wanita Dewasa
}

\section{Nutrition Label Reading Habit Related to Sodium Intake in Adult Woman}

\author{
Dea Dellyana Wahyutia Ady*1, Sri Sumarmi²
}

\begin{abstract}
ABSTRAK
Latar Belakang: Natrium adalah salah satu zat gizi yang wajib ditampilkan di label pangan kemasan. Asupan tinggi natrium meningkatkan resiko peningkatan tekanan darah dan hipertensi. Kebiasaan membaca label gizi dapat berpengaruh terhadap asupan zat gizi, salah satunya natrium.

Tujuan: Tujuan dari penelitian ini adalah untuk menganalisis hubungan kebiasaan membaca label gizi dengan asupan natrium pada wanita dewasa.

Metode: Penelitian cross sectional ini dilakukan pada populasi wanita dewasa di Desa Modong, Kecamatan Tulangan, Kabupaten Sidoarjo dengan 70 orang responden. Teknik pengumpulan sampel menggunakan simple random sampling. Data asupan natrium didapatkan melalui wawancara menggunakan Semi Quantitative Food Frequency Questionnaire (SQ-FFQ). Data kebiasaan membaca label gizi didapatkan melalui wawancara frekuensi membaca label gizi. Hubungan antara kebiasaan membaca label gizi dengan asupan natrium dianalisis menggunakan uji statistic uji chi square.

Hasil: Hasil penelitian menunjukkan terdapat hubungan yang bermakna antara kebiasaan membaca label gizi dengan asupan natrium $(p=0,023)$. Sebagian besar responden jarang membaca label gizi $(40 \%)$ dan mengonsumsi natrium yang berlebih (30\%).

Kesimpulan: Kebiasaan membaca label gizi memiliki hubungan yang bermakna dengan asupan natrium wanita dewasa di Desa Modong, Kecamatan Tulangan, Kabupaten Sidoarjo.
\end{abstract}

Kata Kunci: label gizi, natrium, wanita.

\section{ABSTRACT}

Background: Sodium is one of the nutrients which is mandatory to be displayed in food packaging. High intake of sodium can increase the risk blood pressure elevation and hypertension. The habit of reading the nutrition label can affect in dietary intake, one of them is sodium.

Objective: The purpose of this study was to analyze the association between the habit of reading the nutrition label and sodium intake in female adolescents.

Methods: This study was a cross sectional study with citizens of Modong Village, Tulangan Sub-district, Sidoarjo District with 70 participants. Sample collection used a simple random sampling method. Sodium intake data was collected through interview using Semi Quantitative Food Frequency Questionnaire (SQ-FFQ). Data of habit of reading the nutrition label were obtained through interview in reading nutrition label frequency. Statistical test performed was chi square test.

Result: The results showed that there was a significant relationship between reading habit of nutrition fact with sodium intake among adult woman ( $p=0.023)$. Most respondents rarely read nutrition label $(40 \%)$ and inadequate sodium intake (30\%).

Conclusion: The habit of reading nutrition label is significantly associated with sodium intake in female adolescents in Modong Village, Tulangan Sub-district, Sidoarjo District.

Keywords: nutrition label, sodium, woman

\author{
*Koresponden: \\ deadellyana@gmail.com \\ 1,2Prodi S-1 Gizi Fakultas Kesehatan Masyarakat Universitas Airlangga, Kampus C Mulyorejo, 60115, Surabaya, Indonesia
}




\section{PENDAHULUAN}

Penyebab utama permasalahan kesehatan di dunia salah satunya adalah pola makan yang buruk, yaitu asupan tinggi natrium ${ }^{1}$. Pada umumnya bahan makanan yang mengandung tinggi natrium adalah makanan kemasan. Makanan kemasan merupakan salah satu makanan yang dibuat sebagai makanan yang tahan lama. Pada sebagian besar negara makanan yang tahan lama diproduksi untuk jangka yang lama mengandung kadar natrium yang cukup tinggi².

Salah satu makanan kemasan yang sering dikonsumsi masyarakat Indonesia adalah mie instan. Indonesia merupakan salah satu negara dengan konsumsi mie instan tertinggi kedua di dunia setelah Korea Selatan. Mie instan merupakan salah satu pangan kemasan yang sering dikonsumsi oleh masyarakat Indonesia. Rata-rata konsumsi mie instan masyarakat Indonesia sebesar 63 kemasan per orang per hari3 ${ }^{3}$. Sementara itu, pangan kemasan masih menjadi kebutuhan masyarakat Indonesia dibuktikan dengan rata-rata pengeluaran per kapita perhari untuk membeli pangan kemasan. Asupan pangan kemasan yang tinggi dibuktikan dengan rata-rata konsumsinya $80 \%$ pada anggota persatuan diabetisi Indonesia. Sebagian besar anggota persatuan diabetisi Indonesia mengonsumsi makanan kemasan jenis mie yaitu, sebanyak 133,68 gram/hari ${ }^{4}$.

Peningkatan konsumsi pangan kemasan tidak hanya terjadi pada usia remaja, melainkan pada wanita usia dewasa ${ }^{4}$. Hal tersebut dikarenakan perubahan gaya hidup pada masyarakat saat ini. Perubahan gaya hidup pada masyarakat yang terjadi di berbagai negara di dunia dapat berdampak terhadap perubahan pola konsumsi masyarakat. Pada saat ini masyarakat lebih banyak mengonsumsi makanan dari luar maupun makanan kemasan ${ }^{5}$ Tingginya angka konsumsi pangan kemasan tidak membuat masyarakat lebih memahami label gizi pada pangan kemasan ${ }^{6}$.

Secara nasional sebanyak $18,3 \%$ penduduk Indonesia mengonsumsi natrium melebihi anjuran yang ditetapkan Permenkes Nomor 30 tahun 2013 yaitu tidak lebih dari 2000 mg. Berdasarkan hasil Survey Konsumsi Makanan Individu, sebanyak $3500 \mathrm{mg}$ penduduk Indonesia mengonsumsi garam setiap harinya. Sedangkan rata-rata konsumsi gula dan lemak masyarakat Indonesia adalah 15,7 gram dan 37,4 gram per orang per hari ${ }^{7}$. Jawa Timur merupakan salah satu provinsi yang masuk kedalam sepuluh besar konsumsi natrium tertinggi di Indonesia yaitu sebesar $4,8 \%{ }^{8}$.

Menurut Badan Perlindungan Konsumen Indonesia (BPKN) masih rendahnya masyarakat Indonesia yang memperhatikan komposisi dan informasi nilai gizi label makanan ${ }^{9}$. Salah satu informasi yang dicantumkan dalam makanan kemasan adalah kandungan nilai gizi ${ }^{10}$.

Label gizi merupakan sebuah alat komunikasi meliputi takaran saji dan zat gizi yang digunakan oleh produsen makanan kemasan untuk memberikan informasi terkait kandungan gizi dengan tujuan meningkatkan kesehatan dan perilaku makan saat membeli makanan individu11,12. Membaca label gizi pada makanan kemasan berkorelasi terhadap pemilihan makanan yang sehat ${ }^{13}$. Seseorang yang paham dalam membaca label gizi akan lebih memiliki rasa waspada dalam menentukan asupan yang dikonsumsi seperti salah satunya natrium, agar asupannya tidak melebihi batas yang ditentukan ${ }^{14}$.

Konsumsi natrium yang berlebih, dimana hal tersebut memiliki korelasi terhadap kebiasaan membaca label gizi akan berdampak terhadap kenaikan tekanan darah $^{14}$. Produk makanan kemasan merupakan salah satu sumber terbesar dari energi, lemak, gula dan natrium ${ }^{15}$. Penelitian menunjukan bahwa kebiasaan membaca label gizi lebih banyak dilakukan oleh masyarakat berpendapatan besar, kalangan remaja dan pada masyarakat yang memiliki masalah penyakit kronik $^{13}$.

Terdapat hubungan yang positif antara kebiasaan membaca label gizi dengan konsumsi makanan dan asupan gizi ${ }^{16}$. Pengetahuan terkait gizi dapat mempengaruhi konsumen untuk memahami label gizi. Beberapa konsumen yang memperhatikan label gizi belum tentu memahami label gizi ${ }^{17}$. Keakuratan dalam menuliskan zat gizi pada label pangan, akan mempengaruhi jumlah asupan dari yang dikonsumsi ${ }^{18}$. Masyarakat yang paham cara membaca dan memahami label gizi akan mudah dalam memilih pangan kemasan dan mengonsumsi makanan yang tepat untuk kebutuhan gizi, termasuk yang terkait dengan natrium ${ }^{12}$. Penelitian ini bertujuan untuk melihat apakah kebiasaan membaca label gizi berpengaruh terhadap asupan natrium

\section{METODE}

Penelitian cross sectional ini dilakukan pada bulan April-Mei 2019 di Desa Modong, Kecamatan Tulangan, Kabupaten Sidoarjo. Populasi penelitian adalah wanita usia 40-59 tahun dengan kriteria inklusi menetap di Desa Modong dan bersedia menjadi responden dalam penelitian ini. Besar sampel adalah 70 responden yang dipilih acak menggunakan teknik simple random sampling, sehingga setiap anggota populasi memiliki peluang yang sama untuk terpilih. Penentuan sampel dengan cara mengambil 20 responden pada dua RW dan 30 responden pada satu RW secara acak, dikarenakan hanya terdapat tiga RW di Desa Modong. Sehingga didapatkan responden secara acak. Kriteria inklusi penelitian ini antara lain, menetap di Desa Modong dan bersedia menjadi responden dalam penelitian ini.

Data kebiasaan membaca label gizi diperoleh melalui wawancara dengan menanyakan frekuensi responden membaca label gizi yang dikelompokan menjadi sering, jarang dan tidak pernah. Sedangkan data asupan natrium diperoleh melalui wawancara dengan Semi Quantitative Food Frequency Questionnaire (SQFFQ) dengan metode wawancara. Terdapat 35 bahan makanan yang ditanyakan kepada responden. Asupan natrium dikatakan cukup dan berlebih disesuaikan dengan Permenkes yaitu tidak lebih dari $2000 \mathrm{mg}$.

Kuesioner SQ-FFQ ditanyakan kepada responden dalam kurun waktu satu bulan terakhir. Cara pengelompokannya berdasarkan frekuensi waktu harian, mingguan, bulanan atau bahkan tidak pernah. Pemilihan makanan kemasan berdasarkan hasil Survei Konsumsi 
Masyarakat Indonesia yang sering dikonsumsi dan dari hasil penelitian yang sudah ada ${ }^{7,4}$.Ukuran yang digunakan dalam SQ-FFQ adalah Ukuran Rumah Tangga (URT).

Hasil dari penelitian ini dianalisis menggunakan aplikasi SPSS tipe 21.0. Uji hubungan dalam penelitian ini menggunakan chi square dengan derajad kepercayaan 95\% untuk menganalisis hubungan antara membaca label gizi dengan asupan natrium natrium.

Penelitian ini telah lulus uji etik dari Komisi Etik Penelitian Fakultas Kesehatan Masyarakat Universitas Airlangga dengan nomor sertifikat 120/EA/KEPK/2019 tanggal 17 April 2019. Responden yang tergabung dlaam penelitian ini sudah menyetujui dan menandatangani informed consent.

\section{HASIL DAN PEMBAHASAN}

\section{Karakteristik Responden}

Sebagian besar responden memiliki berusia 4049 tahun atau sebesar $57,1 \%$. Berpendidikan terakhir SMP atau sebesar $37,1 \%$ dan berpenghasilan rata-rata adalah Rp. $1.550 .142 \pm 110.273$ per bulan yang berada dibawah UMK Kabupaten Sidoarjo. Tingkat pendidikan memiliki pengaruh terhadap pemahaman dalam membaca label gizi. Seseorang yang memiliki pendidikan lebih tinggi, akan memiliki wawasan yang lebih baik untuk memahami label gizi daripada seseorang yang memiliki tingkat pendidikan lebih rendah ${ }^{19}$. Pada penelitian ini menunjukan hasil yang sama yaitu responden dengan tingkat pendidikan terakhir lebih rendah memiliki wawasan terkait label gizi yang rendah juga. Pendapatan memiliki fungsi yang cukup penting dalam hal memilik dan mengonsumsi bahan makanan. Bahan makanan yang dikonsumsi mempengaruhi seberapa banyak uang yang dikeluarkan untuk membeli bahan makana tersebut. Sehingga dapat dikatakan bahwa tingkat pendapatan dapat mempengaruhi responden dalam memilih san membeli bahan makanan $^{20}$ (Tabel 1).

Tabel 1. Karakteristik Responden

\begin{tabular}{lcc}
\hline \multicolumn{1}{c}{ Karakteristik } & (n) & (\%) \\
\hline Usia & & \\
40-49 tahun & 40 & 57,1 \\
50-59 tahun & 30 & 42,9 \\
\hline Tingkat Pendidikan & & \\
$\quad$ Tidak Tamat SD & 0 & 0 \\
Tamat SD & 17 & 24,3 \\
Tamat SMP & 26 & 37,1 \\
Tamat SMA & 19 & 27,1 \\
Tamat PT & 8 & 11,5 \\
\hline Pekerjaan & & \\
Tidak bekerja & 41 & 58,6 \\
Pegawai & 2 & 2,9 \\
Wiraswasta & 23 & 32,9 \\
Petani/Nelayan/Buruh & 4 & 5,6 \\
\hline Tingkat Penghasilan & & \\
ZUMK Sidoarjo 2018 & & \\
( $\geq 3.800 .000,00)$ & 2 & 2,9 \\
Di bawah UMK & & \\
(<3.800.000,00) & 68 & 97,1 \\
\hline
\end{tabular}

Pada umumnya, pendidikan mempengaruhi jenis pekerjaan seseorang. Selaras dengan teori yang ada bahwa sebagian besar responden memiliki pendidikan terakhir SMP hanya berstatus sebagai ibu rumah tangga atau tidak bekerja. Hasil penelitian menunjukan bahwa sebagian besar responden tidak bekerja at au sebagai ibu rumah tangga atau sebesar 58,6\%. Seseorang dengan pekerjaan atau profesi yang lebih tinggi, akan mempengaruhi tingkat pendapatan yang lebih tinggi.

Natrium merupakan salah satu elektrolit yang berupa garam anorganik. Elektrolit memiliki peran cukup penting terhadap metabolisme tubuh. Natrium merupakan kation utama yang berada di ekstraseluer dengan nilai normal antara 135 sampai $145 \mathrm{mEq} / \mathrm{L}$. Sekitar 60-65\% natrium berada pada cairan tubuh. Fungsi natrium dalam tubuh adalah mengatur dan memelihara volume plasma, keseimbangan asam-basa dan sebagai fungsi sel normal ${ }^{21}$. Oleh karena itu, menjaga kesimbangan kadar natrium dalam tubuh sangat penting salah satunya dengan mengatur pola makan dengan baik. Sumber utama natrium adalah garam meja atau natrium klorida. Penambahan pengawet makanan pada pangan kemasan turut menyumbang natrium dalam jumlah yang tinggi ${ }^{21}$.

Berdasarkan hasil SQ-FFQ pangan kemasan yang paling sering dikonsumsi dalam frekuensi harian adalah kecap yaitu sebesar 20,6\% dikarenakan kecap merupakan salah satu bahan yang setiap hari digunakan sebagai bahan tambahan pada masakan. Penelitian lain menunjukan hal yang sama, bahwa sebesar $63 \%$ penyumbang asupan natrium terbesar pada responden di Jepang berasal dari kecap manis dan kecap asin ${ }^{2}$. Makanan siap saji seperti sosis dan sejenisnya juga merupakan penyumbang terbesar natrium yaitu $1050 \mathrm{mg} / 100 \mathrm{~g}$ bahan makanan ${ }^{22}$. Penelitian ini menunjukan bahwa asupan natrium yang banyak dikonsumsi dari pangan kemasan dalam frekuensi mingguan chicken nugget $(61,4 \%)$.

Sejalan dengan penelitian lain di United States yang menunjukan bahwa sebagian besar asupan natrium disumbang dari konsumsi makanan beku seperti nugget atau pizza ${ }^{23}$ (Tabel 2). Sebesar 64,3\% responden mengonsumsi keripik kentang dalam frekuensi bulanan. Minuman soda merupakan salah satu pangan kemasan yang hampir tidak pernah dikonsumsi oleh sebagian besar responden (60\%). Rata-rata asupan natrium responden adalah $1592,53 \mathrm{mg}$ dengan standar deviasi \pm 542,2 dengan nilai minimum dan maksimum adalah 336 mg dan $2758 \mathrm{mg}$.

Berdasarkan Tabel 3 uji korelasi menggunakan chi square, menyatakan bahwa kebiasaan membaca label gizi berhubungan dengan asupan natrium pada wanita dewasa. Pada penelitian ini sebagian besar responden mengonsumsi natrium dalam jumlah yang cukup. Sebesar $30 \%$ dari responden mengonsumsi natrium yang berlebih. Berdasarkan kebiasaan membaca label gizi, sebanyak $40 \%$ responden jarang membaca label gizi. Sebagian besar rreponden yang mengonsumsi asupan natrium yang berlebih, jarang membaca label gizi $(42,5 \%)$. Alasan responden jarang membaca dan memperhatikan label gizi adalah karena kurang adanya waktu untuk memperhatikan label. 
Tabel 2. Frekuensi Jenis Makanan Sumber Natrium

\begin{tabular}{|c|c|c|c|c|c|c|c|c|}
\hline \multirow{3}{*}{ Bahan Makanan } & \multicolumn{8}{|c|}{ Frekuensi } \\
\hline & \multicolumn{2}{|c|}{ Harian } & \multicolumn{2}{|c|}{ Mingguan } & \multicolumn{2}{|c|}{ Bulanan } & \multicolumn{2}{|c|}{ Tidak Pernah } \\
\hline & $n$ & $\%$ & $n$ & $\%$ & $n$ & $\%$ & $n$ & $\%$ \\
\hline Biskuit & 0 & 0 & 26 & 37.1 & 23 & 32.9 & 21 & 30 \\
\hline Chicken Nugget & 1 & 1.4 & 43 & 61.4 & 21 & 30 & 5 & 7.1 \\
\hline Ikan sardine & 0 & 0 & 19 & 27.1 & 25 & 35.7 & 26 & 37.1 \\
\hline Kaldu bubuk & 12 & 17.1 & 27 & 38.6 & 16 & 22.9 & 15 & 21.4 \\
\hline Kecap & 20 & 20.6 & 35 & 50 & 14 & 20 & 1 & 1.4 \\
\hline Keju & 2 & 2.9 & 13 & 18.6 & 27 & 38.6 & 28 & 40 \\
\hline Keripik kentang & 3 & 4.3 & 9 & 12.9 & 45 & 64.3 & 13 & 18.6 \\
\hline Kopi kemasan & 0 & 0 & 10 & 14.3 & 32 & 45.7 & 28 & 40 \\
\hline Krakers asin & 1 & 1.4 & 10 & 14.3 & 28 & 40 & 31 & 44.3 \\
\hline Keripik udang & 5 & 7.1 & 10 & 14.3 & 34 & 48.6 & 21 & 30 \\
\hline Mentega & 7 & 10 & 8 & 11.4 & 19 & 27.1 & 36 & 51.4 \\
\hline Mie instan & 4 & 5.7 & 36 & 51.4 & 22 & 31.4 & 8 & 11.4 \\
\hline Minuman soda & 1 & 1.4 & 4 & 5.7 & 23 & 32.9 & 42 & 60 \\
\hline Minuman Berasa lainnya & 4 & 5.7 & 8 & 11.4 & 42 & 60 & 16 & 22.9 \\
\hline Roti tawar & 3 & 4.3 & 24 & 34.3 & 32 & 45.7 & 11 & 15,7 \\
\hline Santan & 5 & 7.1 & 32 & 45.7 & 31 & 44.3 & 2 & 2.9 \\
\hline Saus tomat & 8 & 11.4 & 28 & 40 & 21 & 30 & 13 & 18.6 \\
\hline Sosis sapi & 3 & 4.3 & 10 & 14.3 & 32 & 45.7 & 25 & 35.7 \\
\hline Susu bubuk & 6 & 8.6 & 1 & 1.4 & 40 & 57.1 & 23 & 32.9 \\
\hline Susu Kental Manis & 3 & 4.3 & 10 & 14.3 & 33 & 47.1 & 24 & 34.3 \\
\hline Teh kemasan & 13 & 18.6 & 6 & 8.6 & 42 & 60 & 9 & 12.9 \\
\hline Bakso & 1 & 1.4 & 25 & 35.7 & 42 & 60 & 2 & 2.9 \\
\hline Daging ayam & 4 & 5.7 & 55 & 78.6 & 10 & 14.3 & 1 & 1.4 \\
\hline Daging bebek & 0 & 0 & 6 & 8.6 & 61 & 87.1 & 3 & 4.3 \\
\hline Daging sapi & 0 & 0 & 9 & 12.9 & 60 & 85.7 & 1 & 1.4 \\
\hline Dendeng & 0 & 0 & 9 & 12.9 & 13 & 18.6 & 48 & 68.8 \\
\hline Hati ayam & 0 & 0 & 32 & 45.7 & 25 & 35.7 & 13 & 18.6 \\
\hline Hati sapi & 1 & 1.4 & 29 & 41.1 & 24 & 34.4 & 16 & 22.9 \\
\hline Ikan asin & 12 & 17.1 & 19 & 27.1 & 31 & 44.3 & 8 & 11.4 \\
\hline Ikan pindang & 15 & 21.4 & 39 & 55.7 & 14 & 20 & 2 & 2.9 \\
\hline Ikan tongkol & 4 & 5.7 & 34 & 48.7 & 26 & 37.1 & 6 & 8.6 \\
\hline Jeroan & 7 & 10 & 23 & 32.9 & 32 & 45.7 & 8 & 11.4 \\
\hline Telur Ayam & 5 & 7.1 & 33 & 47.1 & 26 & 37.1 & 6 & 8.6 \\
\hline Telur Bebek & 1 & 1.4 & 6 & 8.6 & 47 & 67.1 & 16 & 22.9 \\
\hline Telur Puyuh & 1 & 1.4 & 15 & 21.4 & 38 & 54.3 & 16 & 22.9 \\
\hline
\end{tabular}

Selain itu sebagian besar responden malas untuk membaca label gizi dikarenakan tidak memahami bagaimana cara membaca dan memahami label gizi. Pada penelitian ini dapat diketahui bahwa wanita pada usia dewasa jarang membaca label gizi. Oleh karena itu, ketika mengonsumsi pangan kemasan tidak memperhatikan zat gizi natrium. Beberapa faktor dapat mempengaruhi kebiasaan membaca label gizi terhadap asupan natrium seperti letak wilayah tinggal. Penelitian ini fokus dilakukan di Desa Modong, dimana Desa Modong merupakan salah satu wilayah pedesaan yang ada di Kabupaten Sidoarjo. Penelitian lain menunjukan bahwa masyarakat yang tinggal di kota lebih sering memperhatikan label gizi ${ }^{24}$. Penelitian tersebut selaras dengan hasil penelitian ini bahwa masih jarang masyarakat di Desa Modong yang memperhatikan label gizi. Sehingga lebih baik masyarakat lebih memperhatikan label gizi sebagai salah satu upaya mengontrol asupan natrium. 
Tabel 3. Hubungan Kebiasaan Membaca Label Gizi dengan Asupan Natrium pada Wanita Dewasa

\begin{tabular}{|c|c|c|c|c|c|c|c|}
\hline \multirow{3}{*}{$\begin{array}{c}\text { Kebiasaan Membaca Label } \\
\text { Gizi }\end{array}$} & \multicolumn{4}{|c|}{ Konsumsi Natrium } & \multirow{2}{*}{\multicolumn{2}{|c|}{ Total }} & \multirow{3}{*}{ P Value } \\
\hline & \multicolumn{2}{|c|}{ Cukup } & \multicolumn{2}{|c|}{ Lebih } & & & \\
\hline & $\mathbf{n}$ & $\%$ & $\mathbf{n}$ & $\%$ & $\mathbf{n}$ & $\%$ & \\
\hline Sering & 6 & 100 & 0 & 0 & 6 & 100 & \\
\hline Jarang & 23 & 57,5 & 17 & 42,5 & 40 & 100 & \\
\hline Tidak Pernah & 20 & 83,3 & 4 & 16,7 & 24 & 100 & \\
\hline Total & 49 & 70 & 21 & 30 & 70 & 100 & \\
\hline
\end{tabular}

\section{KESIMPULAN}

Kebiasaan membaca label gizi berhubungan signifikan dengan asupan natrium pada wanita dewasa. Sebagian besar responden (40\%) jarang memperhatikan label gizi dan 30\% responden mengonsumsi natrium dalam jumlah yang berlebih.

\section{ACKNOWLEDGEMENT}

Peneliti mengucapkan terimakasih kepada kepala Desa Modong, Kecamatan Tulangan, Kabupaten Sidoarjo yang telah memberikan izin sehingga penelitian ini dapat terlaksana dan warga Desa Modong yang menjadi responden pada penelitian ini.

\section{REFERENSI}

1. Skolnik, R. Noncommunicable Diseases Country Profiles 2018. World Health Organization (2018). doi:16/j.jad.2010.09.007

2. Anderson, C. A. M. et al. Dietary Sources of Sodium in China, Japan, the United Kingdom, and the United States, Women and Men Aged 40 to 59 Years: The INTERMAP Study. J. Am. Diet. Assoc. 110, 736-745 (2010).

3. Kementerian Perdagangan. Analisis Dinamika Konsumsi Pangan Masyarakat Indonesia. Pusat Kebijakan Perdagangan Dalam Negeri 1, 67 (2013).

4. Palupi, I. R., Naomi, N. D. \& Susilo, J. Penggunaan Label Gizi dan Konsumsi Makanan Kemasan Pada Anggota Persatuan Diabetisi Indonesia Unit RS Kota Yogyakarta. J. Kesehat. Masy. 11, 1-12 (2017).

5. Hersey, J. C., Wohlgenant, K. C., Arsenault, J. E., Kosa, K. M. \& Muth, M. K. Effects of front-ofpackage and shelf nutrition labeling systems on consumers. Nutr. Rev. 71, 1-14 (2013).

6. Rothman, R. L. et al. Patient Understanding of Food Labels. The Role of Literacy and Numeracy. Am. J. Prev. Med. 31, 391-398 (2006).

7. Prihatini, S., Permaesih, D. \& Julianti, E. D. ASUPAN NATRIUM PENDUDUK INDONESIA: Analisis Data Survei Konsumsi Makanan Individu (SKMI) 2014. Gizi Indones. 39, 15-24 (2017).

8. Kementerian Kesehatan RI. Buku Survei Konsumsi Makanan Individu Indonesia 2014. (2014).
9. No Title. in Hasil kajian BPKN di bidang pangan terkait perlindungan konsumen (2007).

10. BPOM. PerKa BPOM RI No HK.03.1.2. in Badan Pengawas Obat dan Makanan 53, 1689-1699 (2005).

11. Christoph, M. J., Larson, N., Laska, M. N. \& Neumark-Sztainer, D. Nutrition Facts Panels: Who Uses Them, What Do They Use, and How Does Use Relate to Dietary Intake? J. Acad. Nutr. Diet. 118, 217-228 (2018).

12. Anastasiou, K., Miller, M. \& Dickinson, K. The relationship between food label use and dietary intake in adults: A systematic review. Appetite 138, 280-291 (2019).

13. Campos, S., Doxey, J. \& Hammond, D. Nutrition labels on pre-packaged foods: A systematic review. Public Health Nutr. 14, 1496-1506 (2011).

14. J.E., L. et al. Food label use and awareness of nutritional information and recommendations among persons with chronic disease. Am. J. Clin. Nutr. 90, 1351-1357 (2009).

15. Diseases, N. Noncommunicable Diseases Progress Monitor, 2017. Geneva: World Health Organization; 2017. Licence: CC BY-NC-SA 3.0 IGO. (2017).

16. Shangguan, S. et al. A Meta-Analysis of Food Labeling Effects on Consumer Diet Behaviors and Industry Practices. Am. J. Prev. Med. 56, 300-314 (2019).

17. Cowburn, G. \& Stockley, L. Consumer understanding and use of nutrition labelling: a systematic review. Public Health Nutr. 8, 21-8 (2005).

18. Spanos, S., Kenda, A. S. \& Vartanian, L. R. Can serving-size labels reduce the portion-size effect? A pilot study. Eat. Behav. 16, 40-42 (2015).

19. Adilin Mohd Abd Majid, H., Nor Fadillah Ahmad Shariff, S., Aliff Abdul Majid, M., Fattin Fatniah Che Aszahar, N. \& Syazwani Omar, N. Nutritional Labelling: Awareness and Its Effects towards Consumer Behaviour in Purchasing Product. J. Appl. Environ. Biol. Sci. J. Appl. Environ. Biol. Sci. 5, 62-68 (2015).

20. Notoadmodjo. Promosi Kesehatan dan Perilaku Kesehatan. (Rineka Cipta, 2012).

21. Boyd, S. Krauss Food and The Nutrition Process. Foundations and Trends $^{\circledR}$ in Machine Learning 3, (2011). 
22. Allemandi, L. et al. Sodium content in processed foods in Argentina: compliance with the national law. Cardiovasc. Diagn. Ther. 5, 197-206 (2015).

23. Riaz, N., Wolden, S. L., Gelblum, D. Y. \& Eric, J. HHS Public Access. 118, 6072-6078 (2016).
24. Mensah, O. J., Lawer, D. R. \& Aidoo, R. Consumers' Use and Understanding of Food Label Information and Effect on their Purchasing Decision in Ghana; A Case Study of Kumasi Metropolis. Asian J. Agric. Rural Dev. 2, 351-365 (2012). 